\title{
Transformational Leadership and Innovation at the Lebanese Banking Industry
}

\author{
Submitted 10/09/19, 1st revision 11/10/19, $2^{\text {nd }}$ revision 30/10/19, accepted 10/11/19
}

\author{
Sherine Al Ahmad ${ }^{1}$, Nasser Fathi Easa ${ }^{2}$, Nehale Mostapha ${ }^{3}$
}

\begin{abstract}
:
Purpose: Transformational leadership (TL) has been recognized as one of the most important factor influencing innovation. It is argued that this style plays an essential role in developing the process, structure and climate for organizations to become innovative. This research aims to examine the impact of TL on two aspects of innovation namely product and process innovation.

Design/Methodology/Approach: The quantitative and explanatory analysis was taken by using the Structural equations modeling (SEM) with AMOS 20 to examine the relationship between TL and innovation. Research data were collected through a survey method. The sample result was determined by the probability stratified sampling technique of about 310 employees at 27 banks in Lebanon.

Findings: The findings confirmed the importance of TL in enhancing innovation in banking sector. The main implication of the research highlights that individualized consideration is the most important predictor of product and process innovation followed by, inspirational motivation and idealized influence, respectively, whereas, intellectual stimulation has insignificant influence on product and process innovation.

Practical Implications: Findings point to how transformational style of leadership produce better outcomes for the banks by mobilizing employees to engage in innovative products and processes.

Originality/Value: These findings extends the understanding of the processes through which transformational styles of leadership stimulate innovation, and also highlight the benefits gained by cultivating more transformational styles of leadership to generate more innovative outcomes.
\end{abstract}

Keywords: Transformational leadership, product innovation, process innovation, banks, Lebanon.

Paper type: Research article.

\footnotetext{
${ }^{l}$ Corresponding author, PhD Candidate in Business Administration, Beirut Arab University, Beirut, Lebanon, sherine_chaar@hotmail.com

${ }^{2}$ Department of Business Administration, Faculty of Business Administration, Beirut Arab University, Beirut,Lebanon, n.easa@bau.edu.lb

${ }^{3}$ Department of Business Administration, Faculty of Business Administration, Beirut Arab University, Beirut, Lebanon, nehale.mostapha@bau.edu.lb
} 


\section{Introduction}

Today, the banking sector is facing global challenges resulting from the rapid changes in business environment (Jyoti and Dev, 2015). These changes are forcing the banking sector to be more innovative not only to gain but also to survive (Cheung and Wong, 2011; Pieterse et al., 2010). As innovation becomes critical to the survival of organizations and a key factor in achieving competitive advantage, the major concern for managers now is how to boost the innovative behavior among employees (Han et al., 2016). In the academic field, researchers were highly concerned in identifying the factors that stimulate and sustain innovation (Damanpour and Schneider, 2006). Leadership style has been recognized as one of the most important factors affecting innovation positively or negatively (Bojica and Fuentes, 2012; Mittal and Dhar, 2015).

Several leadership styles have been studied, however, the best-known leadership style and the most widely used in leadership literature that linked to innovation is TL (Alnesr and Ramzani, 2019; Michaelis et al., 2010; Zheng et al., 2016). This style plays an essential role in developing the process, structure and climate for firms to become innovative (Chan et al., 2014; Yukl, 2013). TL develops a team attitude and spirit among members which enhances the generation of new ideas (Zheng et al., 2016). Herrmann and Felfe (2013) pointed out that TL practice can stimulate employees to perceive the new task as a challenge that may foster employees' creativity and develop a creative work environment. TL acts as fuel for innovation by promoting Idealized Influence (ID), Inspirational Motivation (IM), Intellectual Stimulation (IS) and Individualized Consideration (IC) among an organisation's members (Bass and Riggio, 2012).

Within developing countries like Lebanon banking sector is facing rapidly changing challenges that require innovation. The banking sector is the core of the Lebanese economy, and banks represent a very active segment approximately $6.2 \%$ compared to other sectors (Hobeika, 2008; Sujud and Hashem, 2017). Prior to the civil war, the Lebanese banking sector was the most advanced banking sector in the Middle East, but it has been seriously affected by the war, as were all other sectors. In 2018, Global Innovation Index ranked Lebanon in the $90^{\text {th }}$ place among 126 countries around the world. This implies that banks presently need to leverage innovation as a driving tool to survive and succeed in highly competitive environments (Maarouf, 2016). To achieve the desired outcomes, TL has been underlined as one of the most important strategic tools that enable innovation (Aragón-Correa et al., 2007).

Previous research has recognized the relationship between TL and innovation (Fontana and Musa, 2017; Zheng et al., 2016). Unfortunately, there is a dearth of empirical research within developing countries specifically Lebanon on this topic. The aim of this paper is to fill that void in the literature by exploring the impact of TL dimensions namely idealized influence, inspirational motivation, intellectual 
stimulation and individualized consideration on product and process innovation within the financial services sector of Lebanon.

The following section is organized as follows. A literature review along with specified constructs is presented first, followed by the development of the main and subordinate hypotheses. The research then describes the research method and results, followed by a discussion of the research's implications, limitations, and future directions.

\section{Theoretical Framework}

Transformational leadership has been recognized as one of the most important factor influencing innovation (García-Morales et al., 2012). Samad (2012) stated that TL is considered important to organizations as they integrate creative insight, persistence and are sensitive to their employees that prompt changes in management innovation regarding practices and processes. Zheng et al. (2016) argued that transformational leader by sharing goals, values and beliefs among team members encourages them to work together effectively and develop innovative ways to succeed. Through the TL, leaders can contribute to the employees' creativity by recognizing individual differences and encouraging more diverse approaches and perspectives (Guo et al., 2016). Within banks context, Qabool and Jalees (2017) found that assisting employees to develop their skills may enhance their creativity, particularly thinking of new ways to do things and using their creative abilities when faced with challenges. Such leaders are also likely to display innovative work behaviour like idea generation, idea promotion and idea realization, both for self-enhancement and for developing the potential of their subordinates (Majumdar and Ray, 2011). Likewise, leadership through strategic, communicative, motivational and personal dimensions enables followers to work creatively in collective processes by encouraging idea generation (Chang, 2016).

The leadership concept had been defined in terms of traits, behaviour, influence, and situation, and accordingly, several styles had developed (Al-Husseini and Talib, 2016; Saenz, 2011). Among these styles, researchers and practitioners have acknowledged TL as an ideal style of leadership for managing organizational transformation and a style to be adopted as leaders strive to cope with the demands of globalization (Riazet et al., 2012).

Bass and Riggio (2012) described TL as a process in which individuals are changed and transformed. It seeks to motivate followers to work beyond self-actualization and to stimulate positive change among them. Leaders raise individuals and groups above self-interests through mainly four different behaviors: idealized influence, inspirational motivation, intellectual stimulation and individualized consideration.

Idealized influence, emphasizes that transformational leaders behave as role models for their subordinates (Yukl, 2013). They are deeply admired, respected and trusted 
(Guay, 2013). They are perceived by their subordinates as having outstanding competence, determination and high standards of ethical and moral behavior (Bass and Riggio, 2012). They argued that leaders have cleared vision and sense of purpose and act according to their deeply held value and belief (Bruch and Walter, 2007). In addition, these leaders sacrifice self-gain for the gain of others, consider subordinates needs over their own needs, and share success and risk with subordinates (Limsila and Ogunlana, 2008).

Regarding intellectual stimulation, leaders behave in ways that encourage followers to be innovative (Yukl, 2013). In practice, transformational leaders ask followers to think differently and to consistently question and develop their own values and assumptions. Leaders mutually work with their subordinates to look at problem in different way, suggest new methods to complete task, and seek different viewpoints in solving problems (Bass and Riggio, 2012). In this style, followers' mistakes are not criticized; instead creativity is openly encouraged (Avolio and Bass, 2002). Even though these leaders encourage subordinates to try new approaches, the emphasis is still on rationality (Limsila and Ogunlana, 2008).

With regard to inspirational motivation, leaders motivate and stimulate the followers by providing challenges and meaning to their work (Bass and Riggio, 2012). These leaders enable followers to involve in envisioning the future, encourage positive expectations about what requires to be performed and determine commitment to the shared vision (Northouse, 2018). It is argued that leaders with inspirational motivation encourage individual and team spirit and collaboration among members (Northouse, 2018). Bass and Riggio (2012) noted that this style can enhance followers' self-confidence to achieve goals. Such leaders, challenge followers with high standards, talk optimistically and with enthusiasm and provide meaning for the task (Bacha, 2014).

When practicing individualized consideration, leaders comprehends and shares others' concerns and considers each individual uniquely. Leaders act as coaches to raise the followers' needs in order to help them to become fully actualized (Lynch, 2012). They show support and recognize different needs, skills, and abilities of their subordinates (Bass and Riggio, 2012). By affirming subordinates' career needs and supporting them with a sense of increased capability to perform their duties. This concept reflects the consideration of followers' abilities and their level of maturity in order to determine their needs for future development (Bi et al., 2012).

These four behavioral patterns perceived as reliable, dependable and trustworthy in resolving organizational challenges (Galuska, 2014). As such, for an organization to flourish in a fast-changing environment, leaders should make full practice of TL (Erkutlu, 2008). Therefore, the current research will focus on TL because of the components of idealized influence, inspiration, intellectual stimulation and individualized consideration, has been suggested as the optimum style for managing change. 
Today's organizations are increasingly focusing on innovation as one of the major competencies required for its success in twenty-first century workplaces (Cekmecelioglu and Gunsel, 2013). Innovative organizations have the capacity to identify new opportunities, technologies, competencies and knowledge assets needed to achieve a competitive advantage (Teece, 2014).

Plessis (2007) defined innovation as the creation of new ideas, products and process which make organizational outcomes possible. De Jong and Hartog (2007) described innovation as the adoption of new products, process and the opening of a new market and their impact on organizational performance. Similarly, Andreeva and Kianto (2011) claimed that innovation refers to the recognition of new ideas, products, services and proper implementation of all these concepts to get new outcomes.

Prior studies have emphasized the importance of various kinds of innovation. For instance, Tidd and Bessant (2011) distinguished between incremental and radical innovation. Damanpour and Aravind (2012) focused on product and process innovation. Schilling (2010) adopted two dimensions, technical and administrative innovation. Hence, it is clear that there are different types of innovation, which vary according to the perspective of the researchers and their field of research.

However, it has been regarded that each kind of radical, incremental, technological or administrative innovation is generally associated to a product or process (Easa, 2012; Valle, 2009). Radical innovation refers to the introduction of new products or application of new processes (Herrmann et al., 2007; Reichstein and Salter, 2006), while incremental innovation is the marginal development in the existing products or processes (Gatignon et al., 2002; Reichstein and Salter, 2006). Technological innovations directly related to the organizational core work activity which comprise both product and process innovations (Jansen et al., 2006; Easa, 2012), while administrative innovation indirectly related to the work activities which relates primarily to process innovation (Al-Husseini, 2014). Despite of different types of innovation, product and process innovation have been widely recommended and studied empirically in the innovation literature (Hoonsopon and Ruenrom, 2012; Liao and $\mathrm{Wu}, 2010)$. Accordingly, the current research will focus on discussing the innovation aspects based on product and process types which are highly integrated categories.

Research into product innovation found it to be of key interest because it is a critical antecedent to product success, which in turn is related with organizational success (Valencia et al., 2010). Product innovation is the modifications made in the end consumer's product and service (Shavinina, 2003). Tsai et al. (2001) measured product innovation by the differentially of products in the market. Meanwhile, Cooper and Edgett (2009) measured it based on the novelty of new products introduced to the market in a timely fashion. Hung et al. (2010), on the other hand, focused on the number of products, and the speed of innovation. 
For the purpose of this research, product innovation within the banking environment is defined as accepting, developing, and implementing new products. It is referred to the degree to which employees seek advanced solutions; develop new service and adopt latest technologies to meet clients need (Birasnav et al., 2013; Easa, 2012; Liao et al., 2017; Obeidat et al., 2016). Regarding process innovation, Gunday et al. (2011) considered it as the application of new, considerably changed production methods and distribution means by making technical, equipment or software changes. Wong and He (2003) indicated that process innovation is the development of new production processes using new equipment and the reengineering of operational processes. This research considers process innovation to be focused on the adopt of novel ways of service, achieved by developing and using latest technology, and introducing changes in management structures, practices and techniques (Easa, 2012; Liao et al., 2017; Obeidat et al., 2016).

\section{Development of Hypotheses}

Several studies have reported that TL is a critical enabler for product and process innovation. In particular, the relationship between the four components of TL: idealized influence, inspirational motivation, intellectual stimulation and individualized consideration in relation to innovation have been investigated.

Regarding idealized influence, leaders determine high standards for moral and spiritual behavior. Such leaders are esteemed, respected and trusted by subordinates (Northouse, 2018), and subordinates will try to imitate their leader. The central core of this phase is the creation of values which motivate and provide purposeful feelings in subordinates and impress them (Fernet et al., 2015). It is found that this style of leadership plays a vital role in helping employees reach and exceed performance expectations, assisting them in both personal and organizational changes (Bai et al., 2012). Suifan and Al-Janini (2017) found that sharing the risks with subordinates and emphasizing the prominence of having a collective sense of the organization's mission, may encourage them to generate new ideas, create solutions to problems and challenge existing procedures. Besides, providing employees with a purpose that transcends their self-interest by appealing to their values, ideals and interests may increase their desire to generate innovative ides (Jia et al., 2018). Furthermore, sharing goals, values and beliefs among team members encourages them to work together effectively and develop innovative ways to succeed (Zheng et al., 2016).

By practicing inspirational motivation, leaders inspire their followers through motivation so as a shared vision insight is facilitated and their commitment is enhanced (Frazier and Bowler, 2015). Thereby, leaders increase the individual and team spirit, strengthen the optimism of followers and encourage their followers about attractive future (Bigharaz et al., 2010). Such leaders raise the understanding of their subordinates about organizational missions and inspire them to perceive the vision (Northouse, 2018). Nusair et al. (2012) indicated that articulating a shared 
vision exhibited by top managers plays an important role in enhancing initiation and implementation of new ideas to attain the organization's objectives effectively. Meanwhile, Overstreet et al.'s (2013) findings suggested that giving encouragement and recognition to staff inspires them to be highly competent and innovative. Similarly, Zheng et al. (2016) claimed that developing a team attitude and spirit among team members enhances the generation of new ideas. Hazen et al. (2012) pointed out that leaders who display inspirational, and goal-oriented behaviours may enable organization to attain desirable outcomes by creating or adopting new products, processes, or systems.

By providing intellectual stimulation, transformational leaders stimulate followers to find out new solutions and rethink about solving organizational problems in an innovative way (Yukl, 2013). In this aspect, the leaders arouse their followers through precise questions, re-explaining the problems and approaching old situations with new ones. transformational leaders with Intellectual stimulation, motivate his followers to take their own decisions and to rethink traditional practices in a creative way (Weib and Sub, 2016). They challenge old assumptions, beliefs, and traditions, and encourages new ways of thinking (Guay, 2013). Through the behavior of intellectual stimulation, leaders can promote employees' creativity by questioning their assumptions and the status quo (Slatten and Mehmetoglu, 2015). Nusair et al. (2012) asserted that encouraging employees intellectually to challenge the current dynamic environment may motivate them to be more innovative. Additionally, Paulsen et al. (2013) findings suggested that leaders who stimulate new ways of exploring problems may encourage the norm of creativity in an R\&D organization climate. Besides, Jia et al. (2018) claimed that showing appreciation and empathy to employees may encourage them to challenge traditional ways and adopt new ones which lead to higher creativity. According to Suifan and Al-Janini (2017), leaders who prevent their employees from thinking outside the box, can hinder their employees' capability to create new knowledge and innovations.

Using individualized consideration, transformational leaders build individual relationships with their subordinates, and esteem their needs, skills, capabilities and ambitions in such a way that facilitates innovation (Bass and Riggio, 2012; Yukl, 2013). The aim of individualized consideration is determining the individuals' needs and strengths. Transformational leaders listen to and care about their followers' ambitions, and contributions, thereby stimulating them to reach their maximum potential (Saenz, 2011). According to Nusair et al. (2012), developing a reciprocal and cooperative individualized relationship with employees and trying to fulfill their needs will improve their creativity. Similarly, Overstreet et al. (2013) asserted that treating staff as individuals, supporting and encouraging their skills may improve the innovation process. Moreover, Paulsen et al. (2013) revealed that helping employees to develop their strengths will affect creativity and innovation particularly, introducing new ideas into the work setting systematically. Building one-to-one relationships with subordinates and realizing their different wants and aspirations will improve innovation in a significant manner (Suifan and Al-Janini, 2017). 
According to Michaelis et al. (2010), leaders, who boost employees' self-esteem, lead product innovation improvement within an organization.

Scanning the literature, the research so far mainly investigated the relationship between TL and different types of innovation such as radical and incremental innovation (Fontana and Musa, 2017); technical and administrative innovation (Chang, 2016) and exploitative and exploratory innovation (Zheng et al., 2016). However, the relationship between TL with product and process innovations has not been examined in depth (Hussain et al., 2017; Jung et al., 2003). Therefore, there is a need for a comprehensive study examining the influence of each component of TL on innovation, particularly on product and process innovation.

The relationship between the two concepts has been studied theoretically (Nanjundeswara and Swamy, 2014; Sethibe and Steyn, 2015) and empirically (Bigharaz et al., 2010; Jung et al., 2008). It was particularly noted that in banks, research which linked TL and innovation adopted different approaches, differing from the current study approach. For instance, several studies defined TL in general (as a single-factor) and identified three components of innovation: idea generation, idea promotion and idea realization (Awais and Tipu, 2014; Qabool and Jalees, 2017).

Other studies, recognized the four dimensions of TL but identified innovation only in general terms (Khattak et al., 2017; Teymournejad and Elghaei, 2017) or TL and innovation were both defined in general terms (Warit et al., 2017). Meanwhile, Fontana et al. (2017) considered the entrepreneurial leadership style and recognized innovation through idea selection, idea development and idea diffusion. It is therefore necessary to conduct a study examining the influence of each component of TL on the product and process innovation in banks.

The majority of empirical studies to investigate the linkage between TL and innovation have focused on developed countries such as the USA (Gilley et al., 2008; Overstreet et al., 2013), Australia (Fitzgerald and Schutte, 2010; Paulsen et al., 2013), Taiwan (Tung and Yu, 2016) and China (Jia et al., 2018). However, the investigation of these phenomena in developing countries suffers from a lack of research (Al-Nasani, 2008; Suifan and Al-Janini, 2017). Therefore, it is highly recommended to extend this research to developing countries (Fritz and Ibrahim, 2010; Khan et al., 2012; Qabool and Jalees, 2017). Lebanon, as one of the Arab and developing countries is a valuable model/sample. Based on the arguments above and notes, this research aims to investigate the following hypotheses:

H 1: Transformational leadership positively influences product and process innovation in the banking sector in Lebanon.

This leads to the following sub-hypotheses: 
H 1.1: Idealized influence positively influences product innovation in the banking sector in Lebanon.

H 1.2: Inspirational motivation positively influences product innovation in the banking sector in Lebanon.

H 1.3: Intellectual stimulation positively influences product innovation in the banking sector in Lebanon.

H 1.4: Individualized consideration positively influences product innovation in the banking sector in Lebanon.

H 1.5: Idealized influence positively influences process innovation in the banking sector in Lebanon.

H 1.6: Inspirational motivation positively influences process innovation in the banking sector in Lebanon.

H 1.7: Intellectual stimulation positively influences process innovation in the banking sector in Lebanon.

H 1.8: Individualized consideration positively influences process innovation the in banking sector in Lebanon.

The aforementioned hypotheses can be graphically summarized in the following research model (Figure 1).

Figure 1. Research Model

\section{H 1}

Transformational Leadership

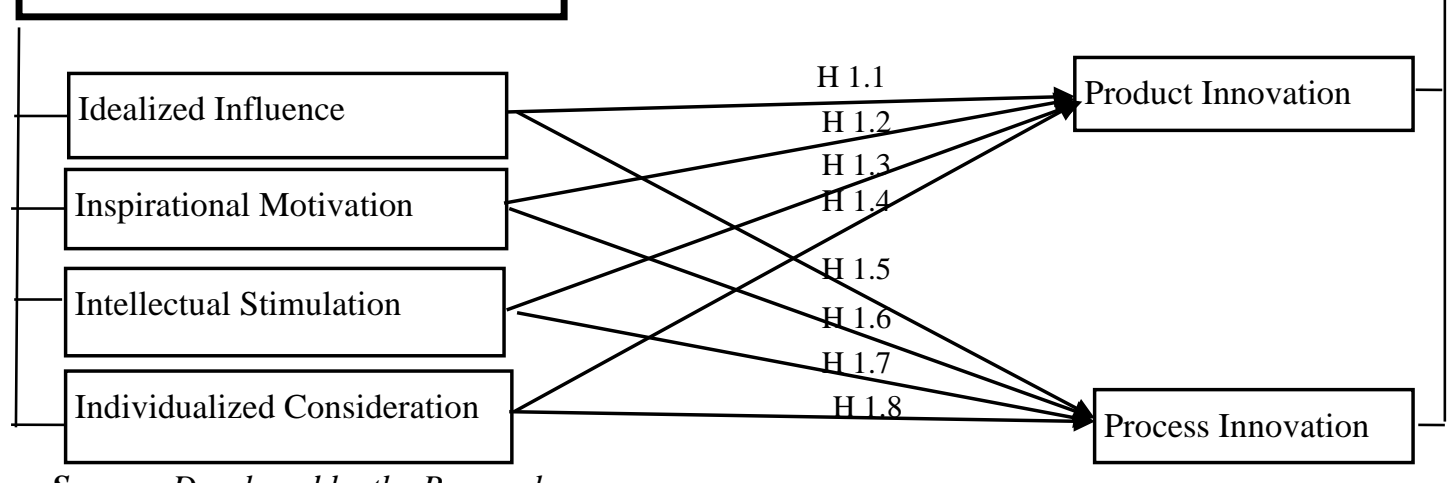

Source: Developed by the Researchers.

\section{Methodology}

This research used quantitative method to examine the relationships between TL processes namely idealized influence, inspirational motivation, intellectual stimulation and individualized consideration and product and process innovation. A self-administered questionnaire and five-point Likert scales ranging from 1-strongly disagree to 5-strongly agree was used in this research. 600 questionnaires were sent to 35 Lebanese banks using e-mail method, of which 310 were returned and usable for analysis from 27 banks. These survey items are available for review in the Appendix. 
TL was measured using the Multi-Factor Leadership Questionnaire (MLQ, Form 5X) developed by Bass and Avolio (2004). The MLQ has been used widely in previous research and considered the best validated measure of TL (Saenz, 2011). In all, 21 items covered four constructs as follows:

1. Idealized influence (six-items) is concerned with feeling proud of leader, building mutual respect; going beyond self-interest; displaying a sense of confidence and power; acting according to value and belief; and considering the ethical and moral effect in each decision.

2. Inspirational motivation (five-items) is concerned with articulating a convincing vision; enabling enthusiasm in what needs to be accomplished; expressing confidence in goals achievement; developing a team attitude and spirit; and talking optimistically about the future.

3. Intellectual stimulation (five-items), is concerned with encouraging their subordinates to look at problem differently; suggesting new ways to complete task; seeking different viewpoints in solving problems; rethinking ideas; and encouraging re-check ideas.

4. Individualized consideration (five-items) is concerned with leaders teaching and coaching; treating group's member as an individual; recognizing the different needs, skills and abilities; developing individual's capabilities; and helping getting what individual wants.

Innovation was measured using twelve items reflecting the development of new ideas related to product and process through adopting latest technologies; introducing new products/service into market; seeking advanced solutions to solve problems; adopting latest technology to improve process; introducing distinctive strategies to manage process; following flexible management strategies; introducing changes in management structures, practices and techniques; and adopting new marketing strategies in promotions and services. Product and process innovation items were developed from Birasnav et al. (2013), Easa (2012), Kim et al. (2012), Prajogo and Sohal (2006), Obeidat et al. (2016), Tan and Nasurdin (2010), Tsai et al. (2008).

The population for this research includes all employees of non-managerial level who work at Lebanese banks through the year 2018 in the Beirut district. A probability stratified sampling technique was adopted, where the entire population was divided into different subgroups. Respondents were proportionally targeted from the different subgroups. The resultant sample represented respondents from 27 banks. A total of 310 complete surveys were received of which $46 \%$ were male and $54 \%$ were female with the overall average age of 35 years. The following table 1 represents some demographic descriptions of the sample $(n=310)$ :

- $80 \%$ Bachelor's degree, $14 \%$ Master's degree, and 6\% high school diploma;

- $36 \%$ less than 10 years working experience, $47 \% 11-15$ years work experience 
Table 1. Demographic Statistics

\begin{tabular}{|c|c|c|}
\hline & Frequency $(\mathrm{N}=310)$ & Percent (\%) \\
\hline \multicolumn{3}{|l|}{ Gender } \\
\hline Male & 143 & $46 \%$ \\
\hline Female & 167 & $54 \%$ \\
\hline \multicolumn{3}{|l|}{ Marital Status } \\
\hline Single & 140 & $45 \%$ \\
\hline Married & 162 & $53 \%$ \\
\hline Divorced & 4 & $1 \%$ \\
\hline Widowed & 4 & $1 \%$ \\
\hline \multicolumn{3}{|l|}{ Age } \\
\hline Below 30 years old & 127 & $41 \%$ \\
\hline 30-35 years old & 124 & $40 \%$ \\
\hline $36-40$ years old & 43 & $14 \%$ \\
\hline 41-45 years old & 13 & $4 \%$ \\
\hline $46+$ years old & 2 & $1 \%$ \\
\hline \multicolumn{3}{|l|}{ Work experience } \\
\hline Less than 10 years & 113 & $36 \%$ \\
\hline $11-15$ years & 145 & $47 \%$ \\
\hline 16-20 years & 41 & $13 \%$ \\
\hline $21-25$ years & 8 & $3 \%$ \\
\hline More than 26 & 3 & $1 \%$ \\
\hline \multicolumn{3}{|l|}{ Education } \\
\hline Business & 141 & $45 \%$ \\
\hline Finance & 90 & $29 \%$ \\
\hline IT & 26 & $9 \%$ \\
\hline Law & 11 & $4 \%$ \\
\hline Other & 41 & $13 \%$ \\
\hline \multicolumn{3}{|l|}{ Level of Education } \\
\hline High school diploma & 18 & $6 \%$ \\
\hline Bachelor's degree & 248 & $80 \%$ \\
\hline Master's degree & 44 & $14 \%$ \\
\hline Doctorate's degree & 0 & $0 \%$ \\
\hline
\end{tabular}

Source: Developed by the Researchers.

\section{Empirical Analysis}

The structural equation modelling (SEM) with Analysis of Moment Structures (AMOS) 21 was employed to examine the impact of idealized influence, inspirational motivation, intellectual stimulation and individualized consideration on product and process innovation. SEM consists of two steps: Measurement model to evaluate the validity and reliability of the constructs and structural model to test the causal relationships among factors (Hair et al., 2013; Loehlin, 2012). 


\subsection{Measurement Model}

The measurement model specifies the relationship between response items (observed variables) and their underlying latent variables (Blunch, 2012; Byrne, 2016). The two main criteria used to assess the measurement model include the goodness of fit of the model and the validity and reliability of the construct (Blunch, 2012; Schumacker and Lomax, 2016). In this regard, Confirmatory factor analysis using AMOS 24 was conducted on all variables to ascertain the validity and reliability for each construct and goodness-of-fit (GOF). In examining the convergent validity, the average variance extracted (AVE) and factor loadings are assessed, the value deemed significant if they were 0.5 or higher (Hair et al., 2013).

Six factors idealized influence, inspirational motivation, intellectual stimulation and individualized consideration, product innovation and process innovation were measured using 28 items. Reliability was evaluated based on the Cronbach's alphas and Composite Reliability (CR), each of which should be greater than 0.7 (Henseler and Sarstedt, 2013; Pallant, 2013). Table 2 indicates that the convergent validity and internal reliability were satisfactory. All factor loadings and the CR and AVE were acceptable and significant.

Table 2. Validity and Reliability of the Measurement Model

\begin{tabular}{|c|c|c|c|c|c|}
\hline Factors & $\begin{array}{l}\text { Code Item } \\
\text { (see } \\
\text { Appendix I) }\end{array}$ & $\begin{array}{l}\text { Factor } \\
\text { Loading } \\
\text { (above 0.5) }\end{array}$ & $\begin{array}{l}\text { AVE } \\
\text { (above } \\
\text { 0.5) }\end{array}$ & $\begin{array}{l}\alpha \\
\text { (above 0.7) }\end{array}$ & $\begin{array}{l}\text { CR } \\
\text { (above } \\
\text { 0.7) }\end{array}$ \\
\hline $\begin{array}{l}\text { Idealized } \\
\text { Influence } \\
\text { F1 }\end{array}$ & $\begin{array}{l}\text { ID1 } \\
\text { ID2 } \\
\text { ID3 } \\
\text { ID4 } \\
\text { ID5 }\end{array}$ & $\begin{array}{l}0.736 \\
0.771 \\
0.735 \\
0.672 \\
0.604\end{array}$ & 0.599 & 0.854 & 0.832 \\
\hline $\begin{array}{l}\text { Inspirational } \\
\text { Motivation } \\
\text { F2 }\end{array}$ & $\begin{array}{l}\text { IM1 } \\
\text { IM2 } \\
\text { IM3 }\end{array}$ & $\begin{array}{l}0.653 \\
0.517 \\
0.511\end{array}$ & 0.598 & 0.811 & 0.712 \\
\hline $\begin{array}{l}\text { Intellectual } \\
\text { Stimulation } \\
\text { F3 }\end{array}$ & $\begin{array}{l}\text { IS1 } \\
\text { IS2 } \\
\text { IS3 } \\
\text { IS4 }\end{array}$ & $\begin{array}{l}0.560 \\
0.691 \\
0.539 \\
0.594 \\
\end{array}$ & 0.638 & 0.792 & 0.703 \\
\hline $\begin{array}{l}\text { Individualized } \\
\text { Consideration } \\
\text { F4 }\end{array}$ & $\begin{array}{l}\text { IC1 } \\
\text { IC2 } \\
\text { IC3 } \\
\text { IC4 }\end{array}$ & $\begin{array}{l}0.576 \\
0.677 \\
0.714 \\
0.520\end{array}$ & 0.612 & 0.786 & 0.718 \\
\hline $\begin{array}{l}\text { Product innovation } \\
\text { F5 }\end{array}$ & $\begin{array}{l}\text { PV1 } \\
\text { PV2 } \\
\text { PV3 } \\
\text { PV4 } \\
\text { PV5 } \\
\text { PV6 }\end{array}$ & $\begin{array}{l}0.670 \\
0.718 \\
0.741 \\
0.663 \\
0.710 \\
0.712\end{array}$ & 0.594 & 0.901 & 0.854 \\
\hline
\end{tabular}




\begin{tabular}{|l|l|l|l|l|l|}
\hline Process innovation & CV1 & 0.658 & 0.714 & 0.902 & 0.828 \\
F6 & CV2 & 0.628 & & & \\
& CV3 & 0.575 & & & \\
& CV4 & 0.689 & & & \\
& CV5 & 0.673 & & & \\
& CV6 & 0.770 & & & \\
\hline
\end{tabular}

Source: SEM - AMOS (21) Output.

Note: $\alpha=$ Cronbach's alpha, $A V E=$ Average Variance Extracted, $C R=$ Composite Reliability, $N=310$.

Discriminant validity was assessed based on rule Fornell and Larcker, 1981 (Hair et al., 2013). According to them, the AVE should exceed 0.5 and should be greater than the squared inter-construct correlations. Table 3 displays that the variances extracted from the constructs were greater than all of the squared correlations between the items.

Table 3. Correlations between the Factors and AVEs

\begin{tabular}{|c|c|c|c|c|c|c|c|c|}
\hline \multirow{2}{*}{ Factors } & \multicolumn{8}{|c|}{$\mathbf{N}=\mathbf{3 1 0}$} \\
\hline & 1 & 2 & 3 & 4 & 5 & 6 & 7 & 8 \\
\hline Idealized Influence & .599 & & & & & & & \\
\hline Inspirational Motivation & .063 & .498 & & & & & & \\
\hline Intellectual Stimulation & .072 & .063 & .638 & & & & & \\
\hline Individualized Consideration & .051 & .087 & .021 & .612 & & & & \\
\hline Product Innovation & .083 & .071 & .035 & .211 & .594 & & & \\
\hline Process Innovation & .236 & .033 & .056 & .231 & .126 & .714 & & \\
\hline
\end{tabular}

Source: SEM -AMOS (21) Output

Notes: The bolded numbers in the diagonal row are the square roots of the average variance extracted (AVE). All correlations among variables are significant at 0.01 level (two-tailed).

The levels of goodness of fit for the measurement model was found to be acceptable, as shown in Table 4. There are two basic indices: (1) the fit indices, including, Goodness of Fit Index (GFI), Root Mean Square Residual (RMR) and Root Mean Square Error of Approximation (RMSEA) (Blunch, 2012); (2) the incremental fit measurement, which includes Adjusted Goodness of Fit Index (AGFI); and Comparative Fit Index (CFI) (Bryne, 2013). The model fit indices of TL constructs are as follows, $\mathrm{GFI}=0.915 ; \mathrm{RMR}=0.027$; $\mathrm{AGFI}=0.882 ; \mathrm{RMSEA}=0.06 ; \mathrm{CFI}=$ 0.947. For innovation the results were $\mathrm{CFI}=0.935, \mathrm{RMR}=0.024$; $\mathrm{AGFI}=0.905$; $\mathrm{RMSEA}=0.065 ; \mathrm{CFI}=0.971$. These results indicate that the model fits the sample data for banks.

Table 4. Fit characteristics Measurement Model First-Order

\begin{tabular}{|l|l|l|l|}
\hline Fit Indices & $\mathbf{N = 3 1 0}$ & Recommended \\
& $\mathbf{T L}$ & Innovation & Criteria \\
\hline GFI & 0.915 & 0.935 & $\geq 0.85$ \\
\hline RMR & 0.027 & 0.024 & $<0.05$ \\
AGFI & 0.882 & 0.905 & $\geq 0.80$ \\
\hline
\end{tabular}




\begin{tabular}{|l|l|l|l|}
\hline RMSEA & 0.060 & 0.065 & $<0.05-0.10$ \\
\hline CFI & 0.947 & 0.971 & $\geq 0.90$ \\
\hline
\end{tabular}

Source: SEM -AMOS (21) Output.

\subsection{Structural Model and Test Hypotheses}

The main aim of this research is to examine the impact of the four components of TL on product and process innovation in banks in Lebanon. The results from SEM demonstrate good fit indices adequate levels of fit for the model, as shown in Table 5. The model fit indices are $\mathrm{CFI}=0.8,69 \mathrm{RMR}=0.027 ; \mathrm{AGFI}=0.844 ; \mathrm{RMSEA}=$ $0.051 ; \mathrm{CFI}=0.948$.

Table 5. Structural Model Fits for the Direct Relationship

\begin{tabular}{|l|l|l|}
\hline Fit indices & $\mathbf{N}=\mathbf{3 1 0}$ & Recommended Criteria \\
& TL-Innovation & \\
\hline GFI & 0.864 & $\geq 0.85$ \\
\hline RMR & 0.031 & $<0.05$ \\
\hline AGFI & 0.839 & $\geq 0.80$ \\
\hline RMSEA & 0.054 & $<0.05-0.10$ \\
\hline CFI & 0.934 & $\geq 0.90$ \\
\hline
\end{tabular}

Source: SEM -AMOS (21) Output.

The results indicate that TL has a significant effect on innovation (product and process). The path coefficients of the impact of TL are confirmatory at these levels as shown in Table (6), idealized influence, inspirational motivation, and individualized consideration are significantly and positively associated with product innovation $(\beta=0.138, C R=3.364 ; \beta=0.165, \quad C R=2.879 ; \beta ; \beta=1.108, \quad C R=8.614)$ respectively; whereas, contrary to expectation, the finding reveals a negative association between intellectual stimulation and product innovation $(\beta=-0.210, \mathrm{CR}$ $=-3.225)$. This indicated that individualized consideration $(\beta=1.108)$ show the highest contribution to product innovation while intellectual stimulation $(\beta=-0.210)$ show significantly negative influence on innovation. Thus, the hypotheses $(\mathrm{H} 1.1$, H1.2, and H1.4) are supported; therefore, the more the idealized influence, inspirational motivation, and individualized consideration the more product innovation is; meanwhile the hypothesis (H1.3) of intellectual stimulation is not supported.

For the process innovation, of the TL dimensions, inspirational motivation $(\beta=$ $0.150, \mathrm{CR}=2.209)$, individualized consideration $(\beta=1.330, \mathrm{CR}=8.749)$ demonstrate significant positive relationships with process innovation, whereas; intellectual stimulation $(\beta=-0.178, \mathrm{CR}=-2.333)$ reveals significant negative predictive capability on process innovation. But only idealized influence $(\beta=0.051$, $\mathrm{CR}=1.052)$ reveal an insignificant effect on process innovation. This indicated that individualized consideration $(\beta=1.330)$ show the highest contribution to process innovation while intellectual stimulation $(\beta=-0.210)$ show negative predictive on 
innovation. Thus, the hypotheses (H1.6, H1.8) are supported; therefore, the more the inspirational motivation, and individualized consideration the more product innovation is; except for hypothesis (H1.5 and H1.7) of idealized influence and intellectual stimulation are not supported.

Table 6. Results for the Direct Effects of TL on Innovation

\begin{tabular}{|c|c|c|c|c|c|c|}
\hline & & & & Resultin & ort & \\
\hline $\begin{array}{l}\text { Hypothes } \\
\text { is }\end{array}$ & $\begin{array}{l}\text { Hypothesis } \\
\text { path }\end{array}$ & Estimate & $\mathrm{CR}$ & $\begin{array}{l}\text { ectional } \\
\text { port? }\end{array}$ & $\begin{array}{l}\text { Signifi } \\
\text { cant }\end{array}$ & $\begin{array}{l}\text { Hypothesis } \\
\text { Supported? }\end{array}$ \\
\hline H1.1 & $\begin{array}{l}\text { Idealized } \rightarrow \\
\text { Product }\end{array}$ & 0.138 & 3.364 & Yes & $* * *$ & Yes \\
\hline $\mathrm{H} 1.2$ & $\begin{array}{l}\text { Inspirational } \\
\rightarrow \text { Product }\end{array}$ & 0.165 & 2.879 & Yes & $*$ & Yes \\
\hline $\mathrm{H} 1.3$ & $\begin{array}{l}\text { Intellectual } \rightarrow \\
\text { Product }\end{array}$ & -0.210 & -3.225 & No & $* *$ & No \\
\hline $\mathrm{H} 1.4$ & $\begin{array}{l}\text { Individualized } \\
\rightarrow \text { Product }\end{array}$ & 1.108 & 8.614 & Yes & $* * *$ & Yes \\
\hline $\mathrm{H} 1.5$ & $\begin{array}{l}\text { Idealized } \rightarrow \\
\text { Process }\end{array}$ & 0.051 & 1.052 & Yes & NS & No \\
\hline H1.6 & $\begin{array}{l}\text { Inspirational } \\
\rightarrow \text { Process }\end{array}$ & 0.150 & 2.209 & Yes & * & Yes \\
\hline $\mathrm{H} 1.7$ & $\begin{array}{l}\text { Intellectual } \rightarrow \\
\text { Process }\end{array}$ & -0.178 & -2.333 & No & $* *$ & No \\
\hline H1.8 & $\begin{array}{l}\text { Individualized } \\
\rightarrow \text { Process }\end{array}$ & 1.330 & 8.749 & Yes & $* * *$ & Yes \\
\hline $\mathrm{H} 1$ & $\begin{array}{l}\text { TL } \\
\text { Innovation }\end{array} \rightarrow$ & 0.804 & 9.455 & Yes & $* * *$ & Yes \\
\hline
\end{tabular}

Source: SEM - AMOS (21) Output

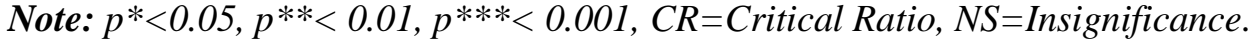

\section{Discussion}

The SEM findings provide strong evidence that TL positively influenced the innovation process and product within Lebanese banks. That is around $75 \%$ of innovative behaviour was explained by TL practices. The following part discusses the relationship between each of TL dimensions and innovation in more detail.

The finding of the quantitative data revealed that $\mathrm{H} 1.1$ provides evidence that idealised influence is positively related to product innovation while H1.5 showed that idealised influence has a non-significant impact on process innovation in the banking sector in Lebanon. This indicates that employees are challenged to adopt innovative approaches in their work to introduce new product, such as generating new ideas, developing new services, embracing new solutions and adopting new technology, when they feel that their leaders trust them. This finding are congruent with the assertion that leaders with idealised influence enhance organisational change by effectively communicating a clear vision and creating a strong network 
with subordinates, leading to greater product innovation (Khalili, 2016; Liao et al., 2017; Mittal and Dhar, 2015; Suifan and Al-Janini, 2017; Vaccaro et al., 2012). On the other hand, the results also showed that employees' belief that the role modeling behavior displayed by their leader is important but, at the same time, is not enough for them to embrace new process innovation such as, adopting new marketing strategies, new technology to improve process, and following a formal process to improve its services to customers. These results consistent Orabi (2016) and Tharnpas and Boon-itt (2015) assertion that trust and respect may not always stimulate the willingness to accept the directives provided by their leader; as a result, leaders who practise idealized influence affect process innovation negatively.

The inspirational motivation is found to be positively related to product and process innovation in the banking sector. This indicated that leaders with inspirational motivation will motivates bank staff and enables them to achieve their greatest potential, thereby assist their bank in its quest for innovation, such as generating new ideas, developing new services, embracing new solutions and adopting new technology, and follows flexible strategies to deal with unexpected changes. These findings are inconsistent with Rafferty and Griffin's (2004) findings, which showed articulating a vision does not always have a positive influence on innovation. However, the results of this research are congruent with the assertion that leaders with inspirational motivation create environment that promote the inspiration and ability of organizational members to be innovative, which, in turn, can gives them direction for successfully developing new products and process (Herrmann and Felfe, 2013; Khalili, 2016; Michaelis et al., 2010; Mittal and Dhar, 2015; Overstreet et al., 2013; Suifan and Al-Janini, 2017; Vaccaro et al., 2012; Zheng et al., 2016).

Regarding intellectual stimulation, it showed a negative impact on product and process innovation. This suggested that the employees surveyed from banks in Lebanon believe that their supervisors behaviour of intellectually stimulating and suggesting new ways of looking at how to complete certain assignments does not motivate them to be creative, come up with new ideas and to adopt innovative approaches at work. In other words, employees are encouraged to seek different perspectives when solving problems and reframe old problems in new aspects and to rethink ideas that have never been questioned before, however, these doesn't help them to generate products and process innovation. As a result, they are not open to try new approaches: for example, generating new ideas, developing new services, embracing new solutions, adopting new technology and follows flexible strategies to deal with unexpected changes.

These findings are consistent with Jaussi and Dionne's (2003) findings, which showed that intellectual stimulation leadership has negative effect on innovation, and with Li et al.'s (2016) study, which indicated that intellectual stimulation did not produce a positive climate for individual innovation. However, these findings don't support previous research conducted by (Jia et al., 2018; Garcia, Matias and Verdu, 2011; Paulsen et al., 2013; Suifan and Al-Janini, 2017) who have suggested that 
leaders demonstrating intellectual stimulation are vital for innovation, particularly product and process.

The finding regarding individualized consideration demonstrates that it is positively related to process and product innovation in the Lebanese banking sector. This suggested that the employees surveyed from banks in Lebanon believe that their supervisors exhibited individualized consideration motivate them to be creative, come up with new ideas and to adopt innovative approaches at work, as such generating new ideas, developing new services, embracing new solutions and adopting new technology, and follows flexible strategies to deal with unexpected changes. These findings are inconsistent with Mokhber et al.'s (2015) findings, which showed that empowerment can have also negative consequences on innovation when the goals of followers are out of alignment or oppose the organization's goals, also with the finding of Jandaghi et al. (2009), which indicated that the unhealthy dependence of followers on leaders and the unwillingness to share power with followers may have negative impact on innovation. However, these findings confirm prior literature suggesting that leaders who use consulting, delegating, and supporting behaviour are able to foster the generation and application of ideas by employees (De Jong and Hartog, 2007; Jia et al., 2018; Mittal and Dhar, 2015; Paulsen et al., 2013; Zheng et al., 2016).

\section{Theoretical and Practical Implications}

The findings of this research have several implications for both theory and mythology. This research examined the impact of TL on innovation in the banking sector in Lebanon. The findings of this research are significant and advances several contributions to the leadership, and innovation literature. From the theoretical perspective, previous research mainly conceptualizes TL in general (as a singlefactor) and linked it with different type of innovation. However, this research is the first attempt to empirically test the roles of the different dimensions of TL on product and process innovation; specifically, it investigates how the components of idealized influenced, intellectual stimulation, inspirational motivation, and individualized consideration impact product and process innovation. The findings of this research confirm that the four components of TL (idealised influence, inspirational motivation, intellectual stimulation, and individualised consideration) influence product and process innovation, and help to provide a better understanding on how the four influential components within TL separately influence innovation.

The majority of empirical studies investigated TL in developed countries such as the USA (Gilley et al., 2008; Overstreet et al., 2013), Australia (Fitzgerald and Nicola, 2010; Paulsen et al., 2013), Taiwan (Tung and Yu, 2016) and China (Jia et al., 2018). However, this research investigated this phenomenon in Lebanon, as one of the Arab and developing countries. The findings indicate that, regardless of whether we are looking at a western or an eastern context, TL plays a significant role in 
promoting a supportive culture and that enhance both product and process innovation in Lebanese banking sector.

From a methodological perspective, this research attains validity and reliability TL and innovation construct in a new geographical region. This provides researchers and academics a valuable model of methodology that might utilize it to track the extent of TL and its effects on product and process innovation in other similar research. The use of quantitative research methods for this research, such as survey was vital for collecting more details about regarding the impact of TL practices on innovation. Survey helps explore the relationship between variables, and help in answering the questions of this research.

This research also provides practitioners with practical insights and suggestions that allow them to identify the style of TL behaviours that contribute in developing a supportive work environment promoting and maximising innovation. For the Lebanese banking sector, the results indicate that individualised consideration behaviour of TL is the most significant predictor of product and process innovation. Therefore, leaders in this sector would consider coaching, building participative individualized relationships through face-to-face communication to gives rise to novel ideas. Besides, tailored training and development programmes for their staff would fulfill their different needs, skills, and abilities which in turn support product and process innovation. This would allow staff to focus on the necessary competencies and capabilities each one have to generate new ideas and become more innovative.

Practicing inspirational motivation behaviour positively affected product and process innovation. Leaders might therefore need to articulate a stimulating vision of the bank future, develops a team attitude and spirit through working groups, project and teamwork would uphold innovative idea. Expressing confidence in employees' abilities and challenge them to a high standard would maximize the capability of generating novel products, services and ideas. Accordingly, this would create an affective commitment among employees to work towards the bank vision and will be motivated to overcome their natural resistance to try challenging work and new things thereby foster employees to come up with new ideas.

The research also found that employing TL behaviours based on intellectual stimulation negatively affected the innovation of product and process. To enable all staff to engage in innovation, banks need to create an innovative climate such as brainstorming sessions, which encouraged them to take initiative and risks, and will be challenged to seek innovative approaches in their work. It is suggested that through challenging the status-quo and encouraging problem reformulation, imagination, intellectual curiosity, and novel approaches will motivate employees to seek alternative perspectives when solving problems and to consider different and new ways of completing assignments. 
Exhibiting idealized influence behaviour is essential for product innovation rather than process innovation. It was found that there is a lack of applying process innovation. In order to enhance this kind of innovation, bank leaders might therefore need to build mutual respect; display sense of power and confidence, and instill pride among the employees to exert extra effort to generate creative ideas. It can be suggested that by creating opportunities for staff to talk about their ideas freely and being alert to changes in the business environment through discussions and negotiation session conducted in formal and informal meetings, this will motivate them to look for new product and adopt new technologies.

Further, this research found that each style of TL plays different role product and process innovation. In this regard, this finding suggests that bank needs to select a leader with the appropriate leadership style with which to achieve its specific objectives. For example, if the bank's objective is to introduce new products or services, then bank needs a leader with intellectual stimulation style who encourages employees to always seek alternative perspectives when solving problems and to consider different and new ways of completing assignments. In addition, bank would also need leader with inspirational motivation style who can set a specific and stable vision for the bank's future goals.

\section{Research Limitations and Further Research}

Although this research provides a number of insights regarding the relationships between TL and innovation in the banking sector in Lebanon, it has its own limitations that should be recognized. This research is limited to focus on the TL style only, therefore it is recommended to explore the impacts of other type of leadership; namely transactional and laissez-faire leadership to discover which is the most influential on product and process innovation among employees. This research was constrained Lebanese banks; thus the results cannot be generalised to other sectors. However, the generalizability of TL and its impact on product and process innovation continues to strengthen as these and other research continue to test the boundaries of national and industry context.

This research investigates quantitatively the relationships between TL and innovation among non-managerial employees. Considering different managerial level, may provide a better understanding of the research topic. This research is limited to use a cross-sectional design, as a result the causal relationships may change in the long term; longitudinal study will overcome this limitation and establish the result. This research focus on the impact of TL on product and process innovation; therefore, it is recommended to consider other type of innovation such as administrative, technological, radical, incremental, exploitative and exploratory innovation. 


\section{References:}

Andreeva, T. and Kianto, A. 2011. Knowledge Processes, Knowledge-Intensity and Innovation: A Moderated Mediation Analysis. Journal of Knowledge Management, 15(6), 1016-1034.

Al-Husseini, S. 2014. The Impact of Leadership Style on Innovation in Iraq's Higher Education Institutions: The Role of Knowledge Sharing. Unpublished PhD Thesis, University of Plymouth, UK, Available from: https://pdfs.semanticscholar.org.

Al-Husseini, S. and Talib, A. 2016. The Effect of Transformational Leadership on Process Innovation through Knowledge Sharing. International Journal of Economics and Management Engineering, 10(6), 2752-2759.

Al-Nasani, A. 2008. Testing the Impact of the Dimensions of Transformational Leadership on Administrative Creativity: A Practical Study of Educational Institutions in Syria. Tishreen Economic and Law Journal, 30(1), 24-52.

Alnesr, B. and Ramzani, S. 2019. The Impact of Transformational Leadership on Innovation through the Mediating Role of Knowledge Sharing in Public and Private Universities of Syria. Journal of Business and Management, 21(2), 76-82.

Aragón-Correa, A., García-Morales, J. and Cordón-Pozo, E. 2007. Leadership and Organizational Learning's Role on Innovation and Performance: Lessons from Spain. Industrial Marketing Management, 36(3), 349-359.

Awais, S. and Tipu, A. 2014. Employees' Involvement in Developing Service Product Innovations in Islamic Banks: An Extension of a Concurrent Staged Model. International Journal of Commerce and Management, 24(1), 85-108.

Avolio, B. and Bass, B. 2002. Developing Potential across a Full Range of Leadership Cases on Transactional and Transformational Leadership. New York, Lawerence Erlbaum Associates.

Bacha, E. 2014. The Relationship between Transformational Leadership, Task Performance and Job Characteristics. Journal of Management Development, 33(4), 410-420. Bass, B. and Avolio, B. 2004. Multifactor Leadership Questionnaire: Manual and Sampler Set, 3rd ed., Redwood City, CA: Mind Garden.

Bass, B. and Riggio, R. 2012. Transformational Leadership, 2nd ed., US, Lawrence Erlbaum Associates, Inc.

Bi, L., Ehrich, J. and Ehrich, L. 2012. Confucius as Transformational Leader: Lessons for ESL Leadership. International Journal of Educational Management, 26(1), 391-402.

Bigharaz, B., Kamalian, A. and Roshan, A. 2010 Relationship between Transformational Leadership and Employee Creativity. International Journal of Applied Business and Economic Research, 13(1), 1-23.

Birasnav, M., Albufalasa, M. and Bader, Y. 2013. The Role of Transformational Leadership and Knowledge Management Processes on Predicting Product and Process Innovation: An Empirical Study Developed in Kingdom of Bahrain. Tékhne-Review of Applied Management Studies, 11(2), 64-75.

Blunch, N. 2012. Introduction to Structural Equation Modeling Using IBMSPSS Statistics and Amos, Sage Publications.

Bojica, M. and Fuentes, M. 2012. Knowledge Acquisition and Corporate Entrepreneurship: Insights from Spanish SMEs in the ICT sector. Journal of World Business, 47(3), 397-408.

Bruch, H. and Walter, F. 2007. Leadership in Context: Investigating Hierarchical Impacts on Transformational Leadership. Leadership and Organization Development Journal, 28(8), 710-726. 
Byrne, M. 2016. Structural Equation Modelling with AMOS: Basic Concepts, Applications, and Programming, 3rd ed., New York: Routledge.

Cekmecelioglu, G. and Gunsel, A. 2013. The Effects of Individual Creativity and Organizational Climate on Firm Innovativeness. Procedia-Social and Behavioral Sciences, 99(6), 257-264.

Chan, S., Liu, M. and Fellows, R. 2014. Role of Leadership in Fostering an Innovation Climate in Construction Firms. Journal of Management in Engineering, 30(6), 1943 5479.

Chang, Y. 2016. Multilevel Transformational Leadership and Management Innovation: Intermediate Linkage Evidence. Leadership and Organization Development Journal, 37(2), 265-288.

Cheung, Y. and Wong, C. 2011. Transformational Leadership, Leader Support, and Employee Creativity. Leadership and Organization Development Journal, 32(7), 656-672.

Cooper, G. and Edgett. S. 2009. Successful Product Innovation: A Collection of Our Best, 1 st ed., Product Development Institute.

Damanpour, F. and Aravind, D. 2012. Managerial Innovation: Conceptions, Processes, and Antecedents. Management and Organization Review, 8(2), 423-454.

Damanpour, F. and Schneider, M. 2006. Phases of the Adoption of Innovation in Organizations: Effects of Environment, Organization and Top Managers. British Journal of Management, 17(1), 215-236.

De Jong, J. and Den Hartog, D. 2007. How leaders Influence Employees' Innovative Behavior. European Journal of innovation management, 10(1), 41-64.

Plessis, M. 2007. The Role of Knowledge Management in Innovation. Journal of Knowledge Management, 11(4), 20-29.

Easa, N. 2012. Knowledge Management and the SECI Model: A Study of Innovation in the Egyptian Banking, Published PhD Thesis, University of Stirling, UK, Available from: https://pdfs.semanticscholar.org.

Fernet, C., Trépanier, S., Austin, S., Gagné, M. and Forest, J. 2015. Transformational Leadership and Optimal Functioning at Work: On the Mediating Role of Employees' Perceived Job Characteristics and Motivation. Work and Stress, 29(1), 11-31.

Fitzgerald, S. and Nicola, S. 2010. Increasing Transformational Leadership Through Enhancing Self-Efficacy. The Journal of Management Development, 29(5), 495505.

Fritz, D. and Ibrahim, N. 2010. The Impact of Leadership Longevity on Innovation in a Religious Organization. Journal of Business Ethics, 96(2), 223-231.

Frazier, L. and Bowler, M. 2015. Voice Climate, Supervisor Undermining, and Work Outcomes: A Group-Level Examination. Journal of Management, 41(3), 841-863.

Erkutlu, H. 2008. The Impact of Transformational Leadership on Organizational and Leadership Effectiveness-The Turkish Case. Journal of Management Development, 27(7), 708-726.

Fontana, A. and Musa, S. 2017. The Impact of Entrepreneurial Leadership on Innovation Management and Its Measurement Validation. International Journal of Innovation Science, 9(1), 2-19.

García-Morales, J., Jiménez-Barrionuevo, M. and Gutiérrez-Gutiérrez, L. 2012. Transformational Leadership Influence on Organizational Performance through Organizational Learning and Innovation. Journal of Business Research, 65(7), 10401050 . 
García-Morales, J., Matías-Reche, F. and Verdú-Jover, J. 2011. Influence of Internal Communication on Technological Proactivity, Organizational Learning, and Organizational Innovation in the Pharmaceutical Sector. Journal of Communication, 61(1), 150-177.

Galuska, A. 2014. Education as a Springboard for Transformational Leadership Development: Listening to the Voices of Nurses. The Journal of Continuing Education in Nursing, 45(1), 67-76.

Gatignon, H., Tushman, L., Smith, W. and Anderson, P. 2002. A Structural Approach to Assessing Innovation: Construct Development of Innovation Locus, Type, and Characteristics. Management Science, 48(9), 1103-1122.

Gilley, A., Dixon, P. and Gilley, W. 2008. Characteristics of Leadership Effectiveness: Implementing Change and Driving Innovation in Organizations. Human Resource Development Quarterly, 19(1), 153-169.

Global Innovation Index, 2018. Available from: https://www.globalinnovationindex.

Guay, P. 2013. The Relationship between Leader Fit and Transformational Leadership. Journal of Managerial Psychology, 28(1), 55-73.

Gunday, G., Ulusoy, G., Kilic, K. and Alpkan, L. 2011. Effects of Innovation Types on Firm Performance. International Journal of Production Economics, 13(2), 662-676.

Guo, J., Gonzales, R. and Dilley, E. 2016. Creativity and Leadership in Organizations: A Literature Review. Creativity: Theories-Research-Applications, 3(1), 27-51.

Hair, F., Black, C., Babin, J. and Anderson, E. 2013. Multivariate Data Analysis, International edition. USA: Pearson Education Limited.

Han, S., Seo, G., Yoon, S. and Yoon, D. 2016. Transformational Leadership and Knowledge Sharing: Mediating Roles of Employee's Empowerment, Commitment, and Citizenship Behaviors. Journal of Workplace Learning, 28(3), 130-149.

Hazen, T., Overstreet, E. and Cegielski, C. 2012. Supply Chain Innovation Diffusion: Going Beyond Adoption. International Journal of Logistics Management, 23(1), 119-134.

Herrmann, A., Gassmann, O. and Eisert, U. 2007. An Empirical Study of the Antecedents for Radical Product Innovation and Capabilities for Transformation. Journal of Engineering and Technology Management, 24(1), 92-120.

Herrmann, D. and Felfe, J. 2013. Moderators of the Relationship between Leadership Style and Employee Creativity: The Role of Task Novelty and Personal Initiative. Creativity Research Journal, 25(2), 172-181.

Hobeika, M. 2008. The Strength of the Lebanese Banking System in the Face of Political Instability, Master edn, International Affairs and Diplomacy, Lebanese American University, Available from: https://laur.lau.edu.lb.

Hoonsopon, D. and Ruenrom, G. 2012. The Impact of Organizational Capabilities on the Development of Radical and Incremental Product Innovation and Product Innovation Performance. Journal of Managerial Issues, 24(3), 250-276.

Hung, R., Yang, B., Bella, M., Gary N. and Kuo, Y. 2010. Dynamic capability: Impact of Process Alignment and Organizational Learning Culture on Performance. Journal of World Business, 45(1), 285-294.

Hussain, S., Abbas, J., Lei, S., Haider, M. and Akram, T. 2017. Transactional Leadership and Organizational Creativity: Examining the Mediating Role of Knowledge Sharing Behavior. Cogent Business and Management, 4(3), 136-166.

Jandaghi, G., Matin, H. and Farjami, A. 2009. Comparing Transformational Leadership in Successful and Unsuccessful Companies. African Journal of Business Management, 3(7), 272-280. 
Jansen, P., Bosch, J. and Volberda, W. 2006. Exploratory Innovation, Exploitative Innovation, and Performance: Effects of Organizational Antecedents and Environmental Moderators. Management Science, 52(1), 61-74.

Jaussi, S. and Dionne, D. 2003. Leading for Creativity: The Role of Unconventional Leader Behaviour. Leadership Quarterly, 14(1), 475-498.

Jia, X., Chen, J., Mei, L. and Wu, Q. 2018. How Leadership Matters in Organizational Innovation: A Perspective of Openness. Management Decision, 56(1), 6-25.

Jung, D., Wu, A. and Chow, C. 2008. Towards Understanding the Direct and Indirect Effects of CEOs' Transformational Leadership on Firm Innovation. The Leadership Quarterly, 19(1), 582-594.

Jyoti, J. and Dev, M. 2015. The Impact of Transformational Leadership on Employee Creativity: The Role of Learning Orientation. Journal of Asia Business Studies, 9(1), 78-98.

Kim, Y., Kumar, V. and Kumar, U. 2012. Relationship between Quality Management Practices and Innovation. Journal of Operations Management, 30(4), 295-315.

Khalili, A. 2016. Linking Transformational Leadership, Creativity, Innovation, and Innovation Supportive Climate. Management Decision, 54(9), 2277-2293.

Khattak, R., Batool, S. and Haider, M. 2017. Relationship of Leadership Styles and Employee Creativity: A Mediating Role of Creative Self-efficacy and Moderating Role of Organizational Climate. Pakistan Journal of Commerce and Social Sciences, 11(2), 698-719.

Li, V., Mitchell, R. and Boyle, B. 2016. The Divergent Effects of Transformational Leadership on Individual and Team Innovation. Group Organization Management, 41(1), 66-97.

Liao, S., Chen, C., Hu, D., Chung, C. and Liu, L. 2017. Assessing the Influence of Leadership Style, Organizational Learning and Organizational Innovation. Leadership and Organization Development Journal, 38(5), 793-808.

Liao, S. and Wu, C. 2010. System Perspective of Knowledge Management, Organizational Learning, and Organizational Innovation. Expert Systems with Applications, 37(2), 1096-1103.

Limsila, K. and Ogunlana, O. 2008. Performance and Leadership Outcome Correlates of Leadership Styles and Subordinate Commitment. Engineering, Construction and Architectural Management, 15(2), 164-184.

Loehlin, C. 2013. The general Factor of Personality: What Lies Beyond?”. Personality and Individual Differences, 54(1), 52-56.

Lynch, M. 2012. A Guide to Effective School Leadership Theories, New York, NY: Routledge.

Majumdar, B. and Ray, A. 2011. Transformational Leadership and Innovative Work Behaviour. Journal of the Indian Academy of Applied Psychology, 37(1), 140-148.

Michaelis, B., Stegmaier, R. and Sonntag, K. 2010. Shedding Light on Followers' Innovation Implementation Behavior: The Role of Transformational Leadership, Commitment to Change, and Climate for Initiative. Journal of Managerial Psychology, 25(4), 408-429.

Maarouf, R. 2016. Internationalization Process of Innovative SMEs in Lebanon: An Analysis with a Conceptual Model. International Business: Concepts, Methodologies, Tools, and Applications, Available: DOI: 10.4018/978-1-4666-9814-7, 333-355.

Mittal, S. and Dhar, L. 2015. Transformational Leadership and Employee Creativity: Mediating Role of Creative Self-Efficacy and Moderating Role of Knowledge Sharing. Management Decision, 53(5), 894-910. 
Mokhber, M. Ismail, W., and Vakilbashi, A. 2011. The Impact of Transformational Leadership on Organizational Innovation Moderated by Organizational Culture. Australian Journal of Basic and Applied Sciences, 5(6), 504-508.

Nanjundeswara, S. and Swamy, R. 2014. Leadership Styles. Advances in Management, 7(2), 57-62.

Northouse, P. 2018. Leadership: Theory and Practice, 8th ed. California, SAGE Publications.

Nusair, N., Ababneh, R. and Bae, Y. 2012. The Impact of Transformational Leadership Style on Innovation as Perceived by Public Employees in Jordan. International Journal of Commerce and Management, 22(3), 182-201.

Henseler, J. and Sarstedt, T. 2013. Goodness-of-Fit Indices for Partial Least Squares Path Modeling. Computational Statistics, 28(2), 565-580.

Obeidat, B., Al-Suradi, M., Masa'deh, A. and Tarhini, A. 2016. The Impact of Knowledge Management on Innovation: An Empirical Study on Jordanian Consultancy Firms. Management Research Review, 39(10), 1214-1238.

Orabi, A. 2016. The Impact of Transformational Leadership Style on Organizational Performance: Evidence from Jordan. International Journal of Human Resource Studies, 6(2), 89-102.

Overstreet, R., Hanna, J., Byrd, T., Cegielski, G. and Hazen, B. 2013. Leadership Style and Organizational Innovativeness Drive Motor Carriers Toward Sustained Performance. The International Journal of Logistics Management, 24(2), 247-270.

Pallant, J. 2013. SPSS Survival Manual: McGraw-Hill Education, UK.

Paulsen, N., Callan, V., Ayoko, O. and Saunders, D. 2013. Transformational Leadership and Innovation in an R\&D Organization Experiencing Major Change. Journal of Organizational Change Management, 26(3), 595-610.

Pieterse, N., Van Knippenberg, D., Schippers, M. and Stam, D. 2010. Transformational and Transactional Leadership and Innovative Behavior: The Moderating Role of Psychological Empowerment. Journal of Organizational Behaviour, 3(1), 609-623.

Prajogo, I. and Sohal, S. 2006. The Integration of TQM and Technology/R\&D Management in Determining Quality and Innovation Performance. Omega, 34(3), 296-312.

Qabool, S. and Jalees, T. 2017. Transformational Leadership and Employee Attributes. Journal of Management Business and Economics, 12(2), 21-43.

Rafferty, E. and Griffin, A. 2004. Dimensions of transformational leadership: Conceptual and empirical extensions. The Leadership Quarterly, 15(3), 329-354.

Reichstein, T. and Salter, A. 2006. Investigating the Sources of Process Innovation among UK Manufacturing Firms. Industrial and Corporate Change, 15(4), 653-682.

Riaz, T., Ramzan, M., Ishaq, M., Akram, U. and Karim, Y. 2012. Transformational Leadership and Employees Career Salience: An Empirical Study. International Journal of Business and Social Science, 3(8), 152-160.

Samad, S. 2012. The Influence of Innovation and Transformational Leadership on Organizational Performance. International Conference on Asia Pacific Business Innovation and Technology Management Procedia-Social and Behavioral Sciences, 57(1), 486- 493.

Saenz, H. 2011. Transformational Leadership. In The Sage Handbook of Leadership, edited by Alan Bryman, David Collinson, Keith Grint, Brad Jackson and Mary Bien, 299310. London, Sage.

Sethibe, T. and Steyn, R. 2015. The Relationship between Leadership Styles, Innovation and Organizational Performance: A Systematic Review. South African Journal of Economic and Management Sciences, 18(3), 325-337. 
Schilling, A. 2010. Strategic Management of Technological Innovation, 3rd ed. New York, McGraw-Hill/Irwin.

Schumacker, E. and Lomax, G. 2016. A Beginner's Guide to Structural Equation Modeling. 4th ed. New York, Routledge.

Shavinina, V. 2003. Understanding Innovation: Introduction to some Important Issues, The International Handbook on Innovation, London, UK, Pergamon.

Slatten, T. and Mehmetoglu, M. 2015. The Effects of Transformational Leadership and Perceived Creativity on Innovation Behavior in the Hospitality Industry. Journal of Human Resources in Hospitality and Tourism, 14(2), 195-219.

Suifan, T. and Al-Janini, M. 2017. The Relationship between Transformational Leadership and Employees' Creativity in the Jordanian Banking Sector. International Review of Management and Marketing, 7(2), 284-292.

Sujud, H. and Hashem, B. 2017. Effect of Bank Innovations on Profitability and Return on Assets (ROA) of Commercial Banks in Lebanon. International Journal of Economics and Finance, 9(4), 35-50.

Tan, C. and Nasurdin, A. 2010. Knowledge Management Effectiveness and Technological Innovation: An Empirical Study in the Malaysian Manufacturing Industry. Journal of Mobile Technologies, Knowledge and Society, 25(3), 13-17.

Teece, J. 2014. The Foundations of Enterprise Performance Dynamic and Ordinary Capabilities in an (Economic) Theory of Firms. The Academy of Management Perspectives, 28(1), 328-352.

Teymournejad, K. and Elghaei, R. 2017. Effect of Transformational Leadership on the Creativity of Employees: An Empirical Investigation. Engineering, Technology and Applied Science Research, 7(1), 1413-1419.

Tidd, J. and Bessant, J. 2011. Managing Innovation: Integrating, Technological, Market and Organizational Change, 4thed., London, John Wiley and Sons Limited.

Tharnpas, S. and Boonitt, S. 2015. A study of CEO Transformational Leadership, Organizational Factors and Product Innovation Performance: Scale Development and a Theoretical Framework. International Journal of Innovation Science, 7(2), 107-126.

Tsai, M., Chuang, S. and Hsieh, W. 2008. Using Analytic Hierarchy Process to Evaluate Organizational Innovativeness in High-tech Industry. Decision Sciences Institute, 19(25), 1231-1236.

Tsai, C., Huang, K. and Kao, C. 2001. The Relationships among Organizational Factors, Creativity of Organizational Members and Innovation Capability. Journal of Management, 18(1), 527-566.

Tung, F. and Yu, T. 2016. Does Innovation Leadership Enhance Creativity in High-Tech Industries? Leadership and Organization Development Journal, 37(5), 579-592.

Vaccaro, G., Jansen, P., Bosch, J. and Volberda, W. 2012a. Management Innovation and Leadership: The Moderating Role of Organizational Size. Journal of Management Studies, 49(1), 28-51.

Valencia, J., Valle, R. and Jimnez, D. 2010. Organizational Culture as Determinant of Product Innovation. European Journal of Innovation Management, 13(4), 466-480.

Valle, V. 2009. Concurrent Engineering Performance: Incremental versus Radical Innovation. International Journal of Production Economics, 119(1), 136-148.

Warit, W, Panuwatwanich K. and Rodney, S. 2017. Exploring Leadership Styles for Innovation: An Exploratory Factor Analysis. Engineering Management in Production and Services, 9(1), 7-17. 
Wong, K. and He, L. 2003. The Moderating Effect of a Firm's Internal Climate for Innovation on the Impact of Public R\&D Support Programs. International Journal of Entrepreneurship and Innovation Management, 3(5), 525-545.

Yukl, G. 2013. Leadership in Organizations, 8th ed., U.S, Pearson Prentice Hall.

Zheng, X., Liu, Z. and Gong, X. 2016. Why Does Leader Attention Scope Matter for Innovation Ambidexterity? The Mediating Role of Transformational Leadership. Leadership and Organization Development Journal, 37(7), 912-932.

Appendix 1: Questionnaire Items

\begin{tabular}{|c|c|c|}
\hline Construct & Code & Items \\
\hline \multirow{5}{*}{$\begin{array}{l}\text { Idealized } \\
\text { Influence }\end{array}$} & ID1 & Makes us feel proud of working with him/her. \\
\hline & ID2 & Acts in ways that build mutual respect. \\
\hline & ID3 & Talks about his/her most important values and beliefs to us. \\
\hline & ID4 & Makes us go beyond our own self-interests for the group. \\
\hline & ID5 & Considers various ethical and moral effect in each decision \\
\hline \multirow{3}{*}{$\begin{array}{l}\text { Inspirational } \\
\text { Motivation }\end{array}$} & IM1 & Develops a team attitude and spirit among us. \\
\hline & IM2 & Articulates a convincing vision of the bank future. \\
\hline & IM3 & Expresses confidence to us that we will achieve the goals. \\
\hline \multirow{4}{*}{$\begin{array}{l}\text { Intellectual } \\
\text { Stimulation }\end{array}$} & IS1 & Suggests new ways of completing the tasks assigned. \\
\hline & IS2 & Enables to seek different viewpoints when solving problems. \\
\hline & IS3 & Encourages us to re-check whether our ideas are correct. \\
\hline & IS4 & Stimulates to rethink ideas that have never been questioned. \\
\hline \multirow{4}{*}{$\begin{array}{l}\text { Individualized } \\
\text { Consideration }\end{array}$} & IC1 & Helps us to develop our capabilities. \\
\hline & IC2 & Treats as an individual rather than just as a member. \\
\hline & IC3 & Considers each one of us has different needs, skills, abilities. \\
\hline & IC4 & Finds out what we want and helps us to get it. \\
\hline \multirow{6}{*}{$\begin{array}{l}\text { Product } \\
\text { Innovation }\end{array}$} & PV1 & Follows a formal process to generate and develop new ideas. \\
\hline & PV2 & $\begin{array}{l}\text { Initiates the development of new services to meet customers' } \\
\text { requirements and market trends. }\end{array}$ \\
\hline & PV3 & $\begin{array}{l}\text { Adopts new technology to provide new services and to improve the } \\
\text { current ones. }\end{array}$ \\
\hline & PV4 & Adopts new solutions to solve problems. \\
\hline & PV5 & Introduces new services into the market before its competitors. \\
\hline & PV6 & Provides new services to improve customers' access to services. \\
\hline \multirow{6}{*}{$\begin{array}{l}\text { Process } \\
\text { Innovation }\end{array}$} & CV1 & Follows a formal process to improve its services to customers. \\
\hline & $\mathrm{CV} 2$ & $\begin{array}{l}\text { Follows flexible management strategies to deal with unexpected } \\
\text { changes. }\end{array}$ \\
\hline & CV3 & Provides improvements in its structures, practices and techniques. \\
\hline & CV4 & $\begin{array}{l}\text { Introduces more developed strategies to manage its processes, in } \\
\text { comparison with competitors' strategies. }\end{array}$ \\
\hline & CV5 & Adopts new marketing strategies in its promotions and services. \\
\hline & CV6 & Adopts new technology to improve its processes. \\
\hline
\end{tabular}

